\title{
Broadening the base of publicly funded health care
}

\author{
Irfan A. Dhalla MD MSc, Gordon H. Guyatt MD MSc, Mark Stabile PhD, Ahmed M. Bayoumi MD MSc
}

Competing interests: See end of article for competing interests.

This article has been peer reviewed.

Correspondence to: Dr. Irfan A. Dhalla, dhallai@smh.ca

CMAJ 2011. DOI:10.1503 /cmaj.100999
$O$ ince 1997 , health care expenditure in Canada has increased much faster than the rate of economic growth. ${ }^{1}$ In particular, the proportion of spending from provincial government funds devoted to health care has increased dramatically. For example, the share in Ontario has increased from $32 \%$ to $46 \%$ over the last 20 years. $^{2}$ Many economists believe that the health care demands on government budgets are likely to increase for the foreseeable future. ${ }^{3}$ The Office of the Parliamentary Budget Officer projects that provincial-territorial government health expenditure is likely to rise from $6.8 \%$ of gross domestic product in 2007 to $10.9 \%$ of gross domestic product in $2050 .{ }^{4}$

To deal with these projected increases in health care expenditure, governments have four options: reduce service volume, ${ }^{5}$ deliver the same volume of service at a lower cost through price reductions or improved efficiency, ${ }^{6}$ limit the types of services that are publicly covered ${ }^{7}$ or raise additional revenue. A comprehensive approach to health care sustainability should explore each option. Nevertheless, most observers agree with the Office of the Parliamentary Budget Officer that public expenditure on health care will increase over the coming decades and will therefore demand additional revenue.

Several health policy analysts ${ }^{3,8,9}$ and at least one provincial government ${ }^{10}$ have recently proposed creative mechanisms to broaden the base of public financing. In this article, we focus on methods that governments can use to raise addi-

\section{KEY POINTS}

- Public expenditure on health care will likely increase over the coming decades, demanding additional revenue.

- Potential sources of revenue include general taxation, elimination of the private health insurance subsidy, sin taxes, earmarked taxes, social insurance and deductibles collected through the tax system.

- The available approaches differ in their equity, efficiency, transparency and political feasibility.

- Raising revenue through general taxation optimizes equity and efficiency. Eliminating the private health insurance subsidy or raising funds through social insurance or sin taxes may allow the health care system to maintain its high level of equity and increase the transparency of funding. tional revenue to publicly finance health care. Our analysis is informed by observational or quasi-experimental studies, economic theory and public opinion surveys.

\section{Options for publicly funding health care}

We evaluate each potential source of revenue according to four domains that we believe are the most important and relevant for comparative analysis: equity, transparency, administrative efficiency and political feasibility (Table 1). We consider a mechanism of revenue generation to be inequitable if the costs are disproportionately borne by people with low incomes. Transparency is maximized when it is clear who is paying and for what the money is being used. A source of revenue is administratively efficient if the costs incurred in raising the revenue are small in proportion to the amount collected.

Our judgement regarding political feasibility relies on a framework that considers institutional structures, values and information. ${ }^{11}$ It is worth noting that political feasibility is necessarily more speculative than the other dimensions; for example, decision-makers may exploit windows of opportunity to permit the implementation of a policy that was previously deemed unfeasible. ${ }^{12}$

\section{General tax revenues}

The predominant method of financing health care in Canada and many high-income countries is through general tax revenues, the largest proportion of which is obtained through income tax. Increasing either personal or corporate income tax rates as a strategy for funding health care has several advantages. First, because income taxes are progressive (i.e., the marginal tax rate increases with income), raising taxes is viewed by many as an equitable way to fund health care. Second, raising money through income taxes is very administratively efficient.

However, the political feasibility of raising income taxes in Canada in the near future is unclear. Although politicians in several countries have proposed to increase income taxes to 
address large budgetary deficits, the prevalent policy direction in most high-income countries over the last decade has been toward reducing taxes and limiting public spending.

\section{Elimination of the private health insurance subsidy}

Most working Canadians receive private health insurance as a benefit of employment. In Canada, private health insurance constitutes a much larger proportion of health care expenditure than it does in most other high-income countries ${ }^{13}$ and typically covers medically necessary services such as prescription drugs, dental care and vision care, as well as discretionary care such as semiprivate hospital rooms and massage therapy.

Often unrecognized is that private health insurance is extensively subsidized by the federal government and all provincial governments except Quebec. This subsidy takes the form of a personal income tax exemption on the employer's contribution to private health insurance premiums. Because the subsidy is proportional to the highest income tax rate paid by the recipient, people with higher incomes benefit more than those with lower incomes. For example, consider two employees who receive $\$ 3000$ per year in private health insurance from their employer. The first employee is in a $40 \%$ tax bracket and would have paid $\$ 1200$ in taxes if she had received the $\$ 3000$ as income. The second employee is in a $15 \%$ tax bracket and would have paid $\$ 450$ in taxes. Therefore, the annual subsidy is worth $\$ 750$ more to the employee with the higher income.

Although the subsidy is inefficient and inequitable, eliminating it would require considerable political will. A government that proposed such an initiative would have to withstand powerful and well-organized opponents, including the insurance industry, those with private health insurance, and the associations and unions that represent them. Furthermore, the elimination of the subsidy might lead some companies to cut this benefit, thereby leaving many Canadians without pharmaceutical coverage. Therefore, the subsidy's elimination may be feasible only if a universal public program were introduced simultaneously. This strategy may advance equity and result in net societal cost savings, but it could increase the share of drug costs borne by governments rather than ameliorating stresses on public finances.

\section{Earmarked taxes}

Taxes that are earmarked for health care are politically appealing because the public generally indicates an increased willingness to pay more for better health care. For example, a government survey in the United Kingdom found that only $40 \%$ of respondents supported a $1 \%$ increase in the income tax rate if it were for unrestricted use, compared with $80 \%$ if revenues were earmarked for health care. ${ }^{14}$

Earmarking can be categorized as strong (where the amount spent on health care is exactly determined by the revenue generated from the earmarked tax) or weak (where revenues generated from the earmarked tax are designated for health care but do not determine the level of total spending)..$^{15}$ The unique advantage of strong earmarking is perfect transparency - each taxpayer knows exactly how much he or she is contributing to the collective costs of health care.

Because earmarking can take many forms, earmarked taxes can be equitable or inequitable. Health care premiums, which are used in several Canadian provinces, are usually highly inequitable. For example, British Columbia's Medical Services Plan has uniform premiums, representing $1.95 \%$ of pretax income for someone earning $\$ 35000$ per year but less than $0.1 \%$ of pretax income for a person earning $\$ 700000$ per year. In contrast, a graduated earmarked income tax varying between $0.5 \%$ and $2.0 \%$ of income would be equitable and, by our estimation, would likely raise sufficient funds to pay for all prescription drug use.

Another form of earmarking that has received considerable attention recently is prefunding. ${ }^{9}$ In

Table 1: Mechanisms for publicly funding health care

\begin{tabular}{|c|c|c|c|c|}
\hline Mechanism for raising revenue & Equity & Transparency & $\begin{array}{c}\text { Administrative } \\
\text { efficiency }\end{array}$ & $\begin{array}{l}\text { Political } \\
\text { feasibility }\end{array}$ \\
\hline Increasing personal or corporate income taxes & Equitable & Low & High & Low \\
\hline Earmarked taxes for health care & Depends on specifics & High & Depends on specifics & High \\
\hline Sin taxes & Controversial & High & Medium & Medium \\
\hline
\end{tabular}


such a model, workers contribute to a fund that is invested and used to pay for health care in the future. Unlike medical savings accounts,$^{16}$ the prefunding models involve collective pooling of contributions. Pooling allows for risk sharing across the population and provides insurance against catastrophically large health care expenditures. A mandatory system of prefunding similar to the Canada Pension Plan would be highly transparent. In addition, it would increase intergenerational equity, in that it would ensure that the current generation would be paying for a large proportion of its health care rather than leaving those payments to the next generation.

\section{Sin taxes}

A special form of a tax that is sometimes earmarked, and could potentially be earmarked for health care, is the sin tax. As levied on tobacco and alcohol, these taxes have been a mainstay of Canadian tax policy for decades. Although further increases in tobacco and alcohol taxes may be problematic because of the consequent increase in smuggling and other illegal activity, levying taxes on sugary beverages and other foods of poor nutritional value is increasingly seen as an option worthy of consideration and public debate. ${ }^{17}$ Indeed, Denmark recently introduced a tax on chocolate, candy and ice cream and will soon be introducing a tax on sugary soft drinks of approximately 6 cents per litre. A tax on saturated fat of approximately $\$ 3$ per kilogram is also planned. ${ }^{18}$

Although likely to be controversial initially, $\sin$ taxes on food and nonalcoholic beverages may in the future become as acceptable as tobacco and alcohol taxes are today. Whether these taxes are fair is a controversial issue. If consumption is highest among people with lower incomes, the poor will pay these taxes disproportionately. However, the poor will also disproportionately receive the health benefits from their reduced consumption due to higher prices. ${ }^{19}$

\section{Social health insurance}

Social health insurance involves employers or employees paying for health care through contributions that are related to income from formal employment. In contrast to private insurance premiums, social insurance premiums do not depend on health status, thereby facilitating risk pooling and broad coverage. These contributions are usually channeled to nonprofit entities that are formally separate from government, and it is these "social insurers" that purchase or deliver health care. ${ }^{20}$ Social health insurance combines earmarking with a degree of separation between government and the health insurer. Given Canada's cur- rent tax structure, many economists believe that increasing social insurance premiums would have a smaller negative effect on employment and economic growth than increasing income taxes or corporate taxes. Another advantage of social insurance is that there tends to be greater public support for the tax because of the closer link between the financing mechanisms and the benefits received. ${ }^{21}$

However, the nature of the earmarking usually produces a situation that is less equitable than that in countries with tax-financed systems. ${ }^{22}$ First, revenue is only collected from formal-employment income, rather than income from all sources. Second, in many countries there are ceilings on the level of income that is used to calculate social insurance contributions. As a result, most countries with social health insurance systems also use revenues from general taxation to either offset risks or to provide coverage for low-income and unemployed people. Many advocates for social health insurance point to supposed competition among the insurers. However, individuals usually have limited or no choice in selecting an insurer, and the competition between insurers is negligible. ${ }^{20}$ For these and other reasons, Iceland, Spain and Korea have abandoned social health insurance, and France, Germany and the Netherlands have recently made substantial reforms to their social health insurance. For example, in 2006, the Netherlands replaced a system in which only some people were eligible for social insurance with a system in which everyone must purchase private health insurance. Private insurers are highly regulated - each insurer must provide a standard benefits package, contribution rates are set by government, and insurers cannot decline to provide insurance to interested individuals. ${ }^{23}$ In Germany, where most people cannot choose their social insurer, the government recently introduced a uniform contribution rate (which it subsequently needed to increase) and began reallocating funds among the various social insurers to adjust for differences in patient risk profiles. ${ }^{24}$

When a single entity is responsible for health care delivery, such as with Alberta Health Services or the National Health Service in the United Kingdom, only the revenue collection function distinguishes such a system from the situation that would exist if the relevant jurisdiction had a single social insurer. If, for example, revenues for the National Health Service were derived from a strongly earmarked tax, as has been proposed, ${ }^{25}$ the social health insurance model and the general taxation model would essentially coalesce. The system could be more or less equitable than general tax revenue, 
depending on whether the strongly earmarked tax was more or less progressive than the current income tax structure.

\section{Deductibles collected through the tax system}

The Quebec provincial government recently proposed a $\$ 25$ deductible per physician visit, to be paid when an income tax return is filed. ${ }^{10}$ Taxpayers with incomes below a certain threshold would have been exempt from payment, and the deductibles would have been capped at $1 \%$ of income. A large body of literature suggests that such deductibles would reduce physician visits in the same way that taxes on alcohol and tobacco reduce consumption of these products. ${ }^{26}$ The evidence also suggests that the reduction in use of health care would have negative health consequences, particularly for the sick, the elderly and the poor. ${ }^{26-28}$ The avoidance of preventive care might also ultimately increase total use of health care. ${ }^{29}$

The Quebec proposal included provisions to protect people with very low incomes, but the provisions would not have sheltered those with incomes just above the threshold from the negative consequences of the deductible. Moreover, projections suggest that the deductible would have raised less than $1 \%$ of the provincial health care budget, even before administrative costs are considered..$^{30}$ Although the deductible would have been highly transparent, opposition from almost all sectors, including physicians' groups, led the Quebec government to abandon the proposal. ${ }^{31}$

\section{Gaps in current knowledge}

Patients and decision-makers would find it helpful to know exactly how much money could be raised via the sources of revenue mentioned here. Although estimates for some mechanisms of revenue generation exist, ${ }^{17,30,32}$ we are unaware of any analyses comparing the various options in terms of their ability to generate revenue. Other dimensions beyond those that we have addressed could also be explored in comparative analyses, such as responsiveness to local preferences, allocative efficiency, cost containment and the effects on economic growth.

\section{Conclusion}

Over the coming years, governments committed to equitable access to health care will likely need to increase revenue to keep pace with the costs of health care. Although raising income taxes to fund health care is equitable and efficient, political feasibility suggests that a combination of additional revenue sources may be the most feasible way forward. Elimination of the private health insurance subsidy would require substantial political will but would be fair and efficient. Augmentation of the general tax revenue base with additional funding from social insurance, prefunding or sin taxes would allow the system to maintain its high level of equity and increase the transparency of funding.

\section{References}

1. Canadian Institute for Health Information. National health expenditure trends, 1975 to 2009. Ottawa (ON): The Institute; 2009.

2. Open Ontario Plan. Speech from the Throne. Ottawa (ON): Government of Ontario; Mar. 8, 2010. Available: www.premier.gov .on.ca/news/event.php?ItemID=11282\&Lang $=$ EN (accessed 2010 June 3).

3. Charting a path to sustainable healthcare in Ontario: 10 proposals to restrain cost growth without compromising quality of care. Toronto (ON): TD Bank Financial Group; 2010. Available: www .td.com/economics/special/db0510_health_care.pdf (accessed 2010 June 3).

4. Askari M, Barnett R, Danforth J, et al. Fiscal sustainability report. Ottawa $(\mathrm{ON})$ : Office of the Parliamentary Budget Officer; 2010. Available: www2.parl.gc.ca/sites/pbo-dpb/documents /FSR_2010.pdf (accessed 2010 July 15).

5. Fisher ES, Bynum JP, Skinner JS. Slowing the growth of health care costs - lessons from regional variation. $N$ Engl J Med 2009;360:849-52.

6. Anderson GF, Reinhardt UE, Hussey PS, et al. It's the prices, stupid: why the United States is so different from other countries. Health Aff (Millwood) 2003; 22:89-105.

7. Oberlander J, Marmor T, Jacobs L. Rationing medical care: rhetoric and reality in the Oregon Health Plan. CMAJ 2001;164: 1583-7.

8. Flood CM, Stabile M, Tuohy CH. Exploring social insurance: Can a dose of Europe cure Canadian health care finance? Montréal (QC): McGill-Queen's University Press; 2008.

9. Stabile M, Greenblatt J. Providing pharmacare for an aging population: Is prefunding the solution? Montréal (QC): Institute for Research on Public Policy; 2010. Available: www.irpp.org/pubs /IRPPstudy/IRPP_Study_no2.pdf (accessed 2010 June 3).

10. 2010-2011 budget: for a more efficient and better funded health-care system. Québec (QC): Finance Quebec; 2010. Available: www.budget.finances.gouv.qc.ca/Budget/2010-2011/en /documents/MoreEfficient.pdf (accessed 2010 June 3).

11. Lomas J. Connecting research and policy. Isuma: Can J Policy Res 2000;1:140-4.

12. Kingdon J. Agendas, alternatives, and public policies. Boston (MA): Little, Brown; 1984.

13. Private health insurance in OECD countries. Paris (FR): Organisation for Economic Co-operation and Development; 2004. Available: www.oecd.org/dataoecd/42/6/33820355.pdf (accessed 2010 June 3).

14. Webb S. Health and hypothecation: A new way of paying for public services? N Econ 2002;8:235-41.

15. Wilkinson M. Paying for public spending: Is there a role for earmarked taxes? Fiscal studies 1994;15:119-35.

16. Shortt SED. Medical Savings Accounts in publicly funded health care systems: enthusiasm versus evidence. CMAJ 2002; 167:159-62.

17. Brownell KD, Farley T, Willett WC, et al. The public health and economic benefits of taxing sugar-sweetened beverages. $N$ Engl J Med 2009;361:1599-605.

18. Danish Tax Reform 2010. Danish Ministry of Taxation. Available: www.skm.dk/public/dokumenter/engelsk/Danish\%20Tax \%20Reform_2010.pdf (accessed 2010 July 15).

19. Brownell KD, Frieden TR. Ounces of prevention - the public policy case for taxes on sugared beverages. $N$ Engl J Med 2009;360:1805-8.

20. Wagstaff A. Social health insurance reexamined. Health Econ 2010;19:503-17

21. Mossialos E, Dixon A, Figueras J, et al. Funding health care: options for Europe. Buckingham (UK): Open University Press; 2002.

22. Wagstaff A, van Doorslaer E. Equity in the finance of health care: some international comparisons. J Health Econ 1992;11: 361-87. 
23. Klazinga N. The health system in the Netherlands. Eurohealth 2008;14:8-9.

24. Busse R. The health system in Germany. Eurohealth 2008;14:5-6.

25. Commission on Taxation and Citizenship. Paying for progress: a new politics of tax for public spending. London (UK): The Fabian Society; 2000.

26. Rasell ME. Cost sharing in health insurance - a reexamination. N Engl J Med 1995;332:1164-8.

27. Lexchin J, Grootendorst P. Effects of prescription drug user fees on drug and health services use and on health status in vulnerable populations: a systematic review of the evidence. Int $J$ Health Serv 2004;34:101-22.

28. Trivedi AN, Moloo H, Mor V. Increased ambulatory care copayments and hospitalizations among the elderly. $N$ Engl $J$ Med 2010;362:320-8.

29. Goldman DP, Joyce GF, Zheng Y. Prescription drug cost sharing: associations with medication and medical utilization and spending and health. JAMA 2007;298:61-9.

30. Stabile M. N-Marandi S. Fatal flaws: assessing Quebec's failed health deductible proposal. Toronto (ON): CD Howe Institute; 2010. Available: www.cdhowe.org/pdf/Working_Paper_Stabile .pdf (accessed 2010 Sept. 28).

31. Peritz I. Quebec drops plan for $\$ 25$ user fee for doctors' visits. Globe and Mail [Toronto] 2010 Sept. 22. Available: www theglobeandmail.com/news/politics/quebec-drops-plan-for-25 -user-fee-for-doctors-visits/article1718505/ (accessed 2010 Sept. 28).

32. Tax expenditures and evaluations 2009. Ottawa (ON): Department of Finance Canada; 2009. Available: www.fin.gc.ca/taxexp -depfisc/2009/taxexp-depfisc09_eng.pdf (accessed 2010 Nov. 8).
Competing interests: Irfan Dhalla is a member of the board of directors of Canadian Doctors for Medicare. Gordon Guyatt and Ahmed Bayoumi are members of the steering committee of the Medical Reform Group. Mark Stabile received payment from the C.D. Howe Institute for review of the Quebec proposal, from General Electric for review of Canadian health care financing and from the Institute for Research on Public Policy for a manuscript on prefunding PharmaCare.

Affiliations: From the Department of Medicine and the Keenan Research Centre of the Li Ka Shing Knowledge Institute, St. Michael's Hospital, and the Departments of Medicine and Health Policy, Management and Evaluation (Dhalla, Bayoumi), University of Toronto, Toronto, Ont.; the Departments of Medicine and Clinical Epidemiology \& Biostatistics (Guyatt), McMaster University, Hamilton, Ont.; and the School of Public Policy and the Rotman School of Management (Stabile), University of Toronto, Toronto, Ont.

Contributors: Irfan Dhalla drafted the article. All of the authors critically revised the manuscript for important intellectual content and approved the final version submitted for publication.

Acknowledgements: The authors are grateful to Tara Kiran, Andreas Laupacis and Arthur Slutsky for feedback on previous versions of this manuscript. 